\title{
Identification of information needs in intellectual capital: exploratory study on the Tunisian financial market
}

\author{
Jihene Ferchichi $^{1 *}$, Robert Paturel $^{2}$ \\ ${ }^{1}$ Department of Accounting and Finance, Faculty of Economic Sciences and Management - University of Tunis Manar - Tunisia \\ ${ }^{2}$ Department of Management-Institute of Business Administration-France \\ *Corresponding author E-mail: cheninijihene@yahoo.fr
}

\begin{abstract}
In an economy concretized by the broadening notion of the intellectual capital and its increasing role in investment decisions, it seems appropriate to conceive the intellectual capital by measuring its perception by 22 Tunisian financial professionals. Therefore, the aim of this work consists, firstly, to enable a better understanding of the intellectual capital of the Tunisian financial market. Secondly, by adopting the Delphi method, we determined the information needs and expectations' consensus in terms of intellectual capital. The results from this research show that the concept of intellectual capital appears well known by the financial actors Tunisians. Besides this research, revealed new aspects of intellectual capital. The Tunisian investors consider these dimensions as important criteria that support making their investment decision.
\end{abstract}

Keywords: Delphi Method; Financial Markets; Informational Needs; Intellectual Capital; Perception.

\section{Introduction}

The evolution of new technologies and the movement of market boundaries more and faster profoundly altered the structure of economies. Indeed, an economy based on the production of goods and the ability to manage the efficient way of material resources, the companies have entered a new era based on intelligence, knowledge, innovation capacity, information management, where the issue of value creation is based, increasingly, on the capacity to manage the intellectual capital. (Bounfour, 2000). Therefore, the share of intangible elements continues to grow in the productive capital of undertakings. Thus, the enlargement of the concept of intangible capital in firms over the last thirty years and its growing importance in the value creation process have demonstrated the financial markets that the value of a business comes much more its intangible capital such as ideas, information, intellectual property, patents, right, reputation or a dominant market position.

Before, these are only the financial dimensions of interest to shareholders. These dimensions will no longer suffice to inform investors about the value of the firm and its growth opportunities. So, we have witnessed in recent years, a significant changing needs of Investors Financial Information. Several studies (Eccles et al. 2001; Lev, 2001; Beattie \& Pratt, 2002a and b ...) demonstrated the importance of developing a communication on the know-how, patents, customers ... all elements belonging to the intellectual capital as defined by Edvinsson and Malone (1997). This evolution of information needs induced significant changes in corporate publishing practices. Béjar (2006) and Buck et al (2003) find that firms wishing to access the capital markets treat the content of their annual reports and publications value their intellectual capital to meet investor expectations.
Recent studies based on the construction of indices from a listing information on intangible capital also show improved corporate practices in this publication domain (Bukh et al., 2003; Fernandez, and Vazquez Montes, 2000; Barth and al., 2000; Eccles and al. 2001, Lev, 2001; Beattie and Pratt, 2002a, 2002b; Chahine and Mathieu 2003; Lev and al., 2003; Cazavan-jeny, 2004; GarciaMeca and Martínez, 2007).

However, despite this improvement and although most firms live in the pleasant illusion that their publication practices meet both criteria of usefulness and appropriateness, investors still showed dissatisfaction. On the other hand, for the data published on the intellectual are efficient and that signals can be established in the financial market, they must be understandable by investors, in line with expectations and satisfactory in relation to their information needs (Béjar, 2006).

Questioning informational investor expectations in terms of intellectual capital is the basis for this research. This article proposes to study the perception of intellectual capital in the financial market. To address this issue, we conduct an opinion survey by financial market professionals as part of an emerging country namely Tunisia, a country that has yet to learn about this area, and make a Census their opinions on the inclusion of these criteria in their process decision making. The choice of the Tunisian context is motivated by a desire to extend the previous literature having focused on the general theme of intellectual capital in a specific context of an emerging country. Indeed, this context remains not still operated by researchers despite the Tunisian socio-economic environment is undergoing profound changes in recent years and to follow the trend in developed countries. In addition, it is justified by the existence of a multitude of institutional initiative in Tunisia, for the encouragement to practices related to intellectual capital.

The main objective of this study is to underline the perception of intellectual capital by Tunisian financial professionals. We ask, in 
particular, to know the representation of financial analysts and portfolio managers in relation to the concept of intellectual capital. Secondly, we intend to determine their intellectual capital information needs on the financial market.

The remainder of this paper is organized as follows. Section 2 reviews the previous theoretical and empirical research; the methodology and study design are discussed in the third section; the fourth section presents the test results; and the final section of the paper summarizes the conclusions, describes limitations, and discusses implications for future research.

\section{Literature review}

The broadening notion of the intellectual capital and its increasing role in investment decisions have provided evidence on the financial markets that the value of a company comes from its intellectual capital. Therefore, we have witnessed in recent years, significant changing needs of Investors Financial Information. The previous studies demonstrated the importance of developing a communication concerning intellectual capital. This evolution of information needs induced significant changes in corporate publishing practices. Béjar (2006) and Buck et al (2005) find that firms wishing to access the capital markets treat the content of their annual reports, and publications value their intellectual capital to meet investor expectations.

In this context, several empirical studies have focused on identifying the most information expected by financial market participants regarding intellectual capital. Mavrinac and Siesfield (1997) appreciated the usefulness of intellectual capital information. This survey was to analyze the weight of non-financial factors in decisions of financial market participants, to determine the most important. This study is based on a survey of 275 US portfolio managers (representing 14\% of the profession) of all types of financial institutions (pension funds, insurance companies, banks) and content analysis of 300 reports from independent experts. The nonfinancial information (relating to be intellectual capital) are important indicators to judge the inner workings of business and the actual implementation of their strategy. The importance given to non-financial information by investors was one of the questions: $25 \%$ of investors, non-financial factors influence for more than $50 \%$ their decision, $60 \%$ of them, this influence is between 20 and $50 \%$. On average, $35 \%$ of the investment decision is governed by non-financial data. This figure goes up to $67 \%$ when including non-financial data in the company's image. Indeed, the implementation of the strategy, innovation, increased market share and the personal characteristics of leaders are considered more important information by users as the evaluation of earnings or earnings per share. To deepen their study, and Mavrinac Siesfield (1997) selected the most expected information by users. Thus, the second part of this class survey in order of importance such information. The most expected non-financial information is shown in Table 1.

Table 1: The Most Expected Non-Financial Information

\begin{tabular}{ll}
\hline Non-Financial information & Average rating:: (0 to 7) \\
\hline Existence of Firm stratgy & 6.26 \\
Leader credibility & 6.16 \\
Quality of Firm Strategy & 5.92 \\
Innovation & 5.77 \\
Ability to attract employees & 5.61 \\
Market share & 5.60 \\
Experience of leaders & 5.54 \\
Quality of remuneration policies & 5.48 \\
Research and development & 5.40 \\
Process quality & 5.34 \\
Customer Satisfaction & 5.33 \\
\hline
\end{tabular}

Source: Mavrinac and Siesfield (1997)

The findings of this study showed that investors place significant attention to certain criteria such as the implementation of the strategy, the credibility of the management, the quality of the strategy, the company's innovation capacity in its market and the capacity to remember talented people. This information is part of the major concerns for users who wish to evaluate the firm performance.

The study of Bournemann et al.'s research support the findings of Mavrinac and Siesfield (1997) that information for strategy implementation, market share, innovativeness and the company's ability to attract and retain talented employees are crucial. The results point towards a need for companies to adopt a more comprehensive approach to managing intellectual capital. Successful companies were also found to manage intellectual capital better than fewer successful firms.

These studies were largely confirmed by the Frotiee and Andrieu (1998) research in which it appears that a number of non-financial information is particularly important for users. Indeed, this researcher has shown that users have a strong interest in information measuring the quality of production processes, its ability to innovate and customer satisfaction. The authors have found that the forecast errors decrease proportionally with the increase of analyzes based on intellectual capital information. The latter can exceed a superficial analysis of the company incorporating elements related to its strategy, organization, management and its customers. However, the authors believe that disclosure in this area does not meet the user expectations. The result of this study is shown in Table 2.

Table 2: The Usefulness of Non-Financial Indicators by Investors

\begin{tabular}{|c|c|c|c|}
\hline Indicators & $\begin{array}{l}\text { Financial indi- } \\
\text { cators (F) Non- } \\
\text { financial indica- } \\
\text { tors (NF) }\end{array}$ & $\begin{array}{l}\text { Importance } \\
\text { of indicators }\end{array}$ & $\begin{array}{l}\text { Adequacy needs } \\
\text { versus the cur- } \\
\text { rent publication }\end{array}$ \\
\hline Market Growth & $\mathrm{NF}$ & $92 \%$ & $84 \%$ \\
\hline Earnings & $\mathrm{F}$ & $92 \%$ & $92 \%$ \\
\hline Investments & $\mathrm{F}$ & $90 \%$ & $92 \%$ \\
\hline Innovativeness & $\mathrm{NF}$ & $90 \%$ & $77 \%$ \\
\hline Cash Flows & $\mathrm{F}$ & $90 \%$ & $90 \%$ \\
\hline $\begin{array}{l}\text { Quality of corpo- } \\
\text { rate strategy }\end{array}$ & $\mathrm{NF}$ & $86 \%$ & $84 \%$ \\
\hline quality products & $\mathrm{NF}$ & $84 \%$ & $31 \%$ \\
\hline $\begin{array}{l}\text { Investment in R } \\
\text { \& D }\end{array}$ & $\mathrm{F}$ & $84 \%$ & $90 \%$ \\
\hline Production cost & $\mathrm{F}$ & $84 \%$ & $84 \%$ \\
\hline Market share & $\mathrm{NF}$ & $82 \%$ & $63 \%$ \\
\hline $\begin{array}{l}\text { Employee expe- } \\
\text { rience }\end{array}$ & $\mathrm{NF}$ & $73 \%$ & $43 \%$ \\
\hline Customer loyalty & $\mathrm{NF}$ & $64 \%$ & $18 \%$ \\
\hline $\begin{array}{l}\text { R \& D producti- } \\
\text { vity }\end{array}$ & $\mathrm{NF}$ & $61 \%$ & $12 \%$ \\
\hline $\begin{array}{l}\text { Intellectual Pro- } \\
\text { perty }\end{array}$ & $\mathrm{NF}$ & $59 \%$ & $39 \%$ \\
\hline $\begin{array}{l}\text { customer satis- } \\
\text { faction }\end{array}$ & $\mathrm{NF}$ & $57 \%$ & $8 \%$ \\
\hline Quality processes & NF & $55 \%$ & $29 \%$ \\
\hline
\end{tabular}

Source: Andrieu and Frotiée (1998)

Thus, this study has largely confirmed that of Mavrinac and Siesfield (1997), demonstrating the relevance of non-financial measures for evaluating companies. They showed that the forecast errors decrease proportionally with the increase in the frequency of the tests on non-financial elements of performance. The share of non-financial information in decision of an investor decision is between $20 \%$ and $39 \%$ for more than $20 \%$ of respondents. The variety of items considered critical in the analysis of the economic situation of a company shows that investors rely on a variety of indicators to decide the management of their assets. Non-financial information helps to overcome a superficial analysis of the company by integrating elements related to its strategy and organization, as well as components relating to intellectual capital. Miller (1999) determined the top four information to be leadership skills, employee satisfaction, and employee motivation and there experience.

More recently, basing their study on 105 experienced financial analysts selected from among the largest financial institutions in London, Breton and Taffler (2001) were able to conclude that analysts in their investment recommendations give significant attention to certain intellectual indicators. They favor the imple- 
mentation of the strategy, the credibility of the; management and the quality of the strategy. This information is part of the major concerns for users who wish to evaluate a firm value creation. Béjar (2006), from a survey conducted in France with financial analysts and portfolio managers, was able to determine the components of intellectual capital as perceived by financial market professional: The direction and supervision of the company, employees, organization, Innovation, environmental and customer satisfaction.

Curado (2008), using a qualitative approach, tried to determine the perceptions of knowledge management and intellectual capital in the banking industry. This study showed some interesting results, who confirmed the theoretical intellectual capital literatures, as well as specifying the value given to intellectual capital by the banks that participated in the study.

Ahmed and Hussainey (2010) explored managers' and auditors 'perceptions on intellectual capital measurement and reporting in Egyptian companies. This study showed some interesting results. They find significant differences between respondents' rates on intellectual capital indicators. These differences in perception between the two groups are due to the industry sectors used in this study. In addition, the study showed that information disclosure on intellectual capital is very low in the companies listed on the Egyptian stock market. Similarly, this study indicated that the control information on intellectual capital in annual reports is difficult to implement. Finally, the authors have determined that work experience is the main determinant of manager' perception on intellectual capital indicators; however, professional education is the main determinant of external auditors' perceptions on intellectual capital indicators.

Ferreira and Martinez (2011) emphasize the influence intellectual capital has on employees' perceptions as related to both firm investments and productivity levels. Results show that companies with a high level of disclosure on Structural Capital have a lower perception of investment in human resources and research, as well as a higher perception of investment in marketing and sales. Moreover, employees of companies with higher Structural Capital scores also have higher perceptions of productivity. On the other hand, organizations with higher investment in Customer Capital tend to be associated with a lower perception of organizational productivity.

\section{Methodology and design}

\subsection{The use of exploratory and qualitative approach: Delphi method}

To identify the perception of the Tunisian financial market professionals of the importance of intellectual capital built by companies and reveal their expectations in regard to disclosure of information on these topics, we chose to Like many researchers (Béjar, (2006), Belal and Roberts (2010)) following a qualitative approach. In this regard, the investigative tools are selected, respectively, focus groups, semi-structured interviews and questionnaires.

In order to get a consensus view on the part of investors on their information needs on intellectual capital and the importance they attach to this information in the business assessment process, we realized our questionnaire by applying the Delphi method. This is an iterative method well known, with feedback from the group information, which provides data reflecting a consensus on the expert panel considered. The final information is thus richer than the simple average (or median) of a panel of experts, since from the second step of the method, the experts must take into account assessments of the rest of the panel. In order to get a compromise between satisfactory results and our constraints means and time, we have achieved three successive iterations.

Moreover, before starting this exploration, we will conduct financial market actors to generate survey items or items that make up the intellectual capital as they perceive it. The completion of this investigation is a preparatory step to initiate a second round of interviews and discussions with financial market professionals whose objective is to select the information on intangible capital most relevant for estimating the value of the firm.

After fixing the list of information from the exploration, we chose to equip our items in a Likert scale of five levels. This scale construction technique is more manageable than other techniques developed for the sake of consistency and investigation of nature that involves a solicitation of experts three times in an iterative manner ( 3 questionnaires). Thus, it is necessary to choose a scale of easy understanding as the Likert scale. Moreover, it is insensitive to the collection method, which is also an advantage. The choice of the number of points within the range ( 5 levels) was dictated by the desire to simplify the task of respondents, given the relative length of the questionnaire and the information often gives rise to reflection. Indeed, a 7-point scale could also be considered, but in the five levels of response arrangements require the respondent to take a clear decision. Thus, for each information on intellectual capital, a rating scale is proposed. This is a scale of importance to the following five levels: Very low importance, fairly low importance, Moderate importance, Strong enough importance, Very high importance.

The expert opinion is sought in the form of a score of 1 to 5 , expressing the importance it attaches to the criterion in question to assess the company on the financial market.

\subsection{Sample selection}

The target population of the survey consists of financial market actors involved in financial evaluations of companies and investment decisions: financial analysts and portfolio managers

Our choice to focus on this particular category of users of financial information was made for several reasons: the importance of these users' intermediary role in the chain of economic information, their ability to explain their specific needs for information and their capacity to guide the investors' behavior in the financial market (Healy and Palepu, 2001). In this sense, our survey was conducted among 22 financial professionals: 12 financial analysts and 10 portfolio managers. Table 3 presents a summary of sample of the respondent's characteristics.

Table 3: Characteristics of the Respondents'sample

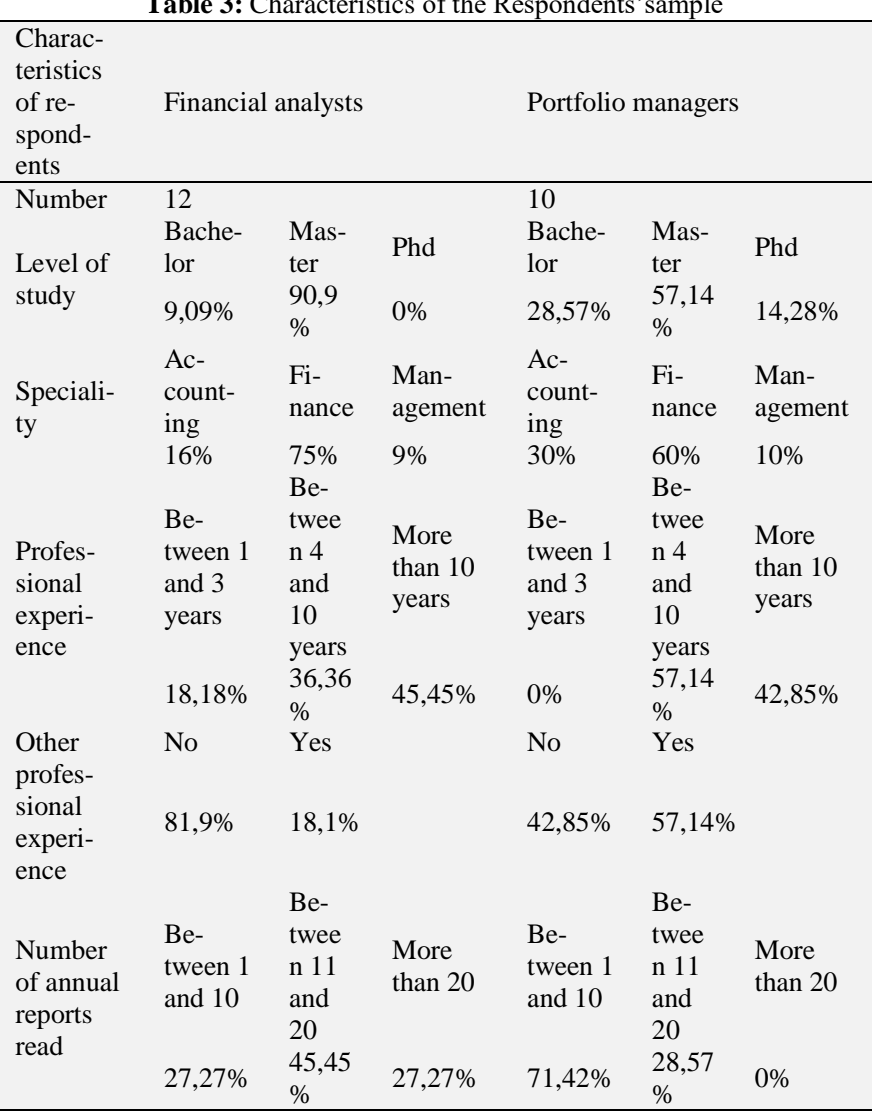




\subsection{Statistical tools}

To assess the degree of convergence between the successive stages of the Delphi method, we were inspired by the approach proposed by Schmidt (1997). In order to measure the significance of this convergence, Schmidt (1997) proposes to charge a Kendall test to give a measure of agreement of respondents. Table 4 helps guide the researcher in the interpretation of W Kendall:

Table 4: Interpretation of the Kendall W

\begin{tabular}{ll}
\hline $\mathrm{W}$ & Interpretation \\
\hline 0.1 & very low level of consensus \\
0.3 & Low level of consensus \\
0.5 & Acceptable level of consensus \\
0.7 & High level of consensus \\
0.9 & Very high level of consensus \\
\hline
\end{tabular}

Source : Schmidt (1997)

\section{Empirical results}

The Delphi study allowed us to perceive the intellectual capital in an own perspective to the financial market and determine by consensus the information about intellectual capital most relevant to the financial market. The consensus reached on the information needs of investors in the intellectual capital is the result of four steps. In the first step, the exploratory study conducted with financial analysts and portfolio managers allowed to propose a conceptualization of own intellectual capital to the Tunisian financial market consists of 49 items. We have grouped these components into 9 categories of information. Table 5 presents the results of the exploratory study of intellectual capital as perceived by the Tunisian financial market:

Table 5: The Conceptualization of Intellectual Capital by the Tunisian Financial Market

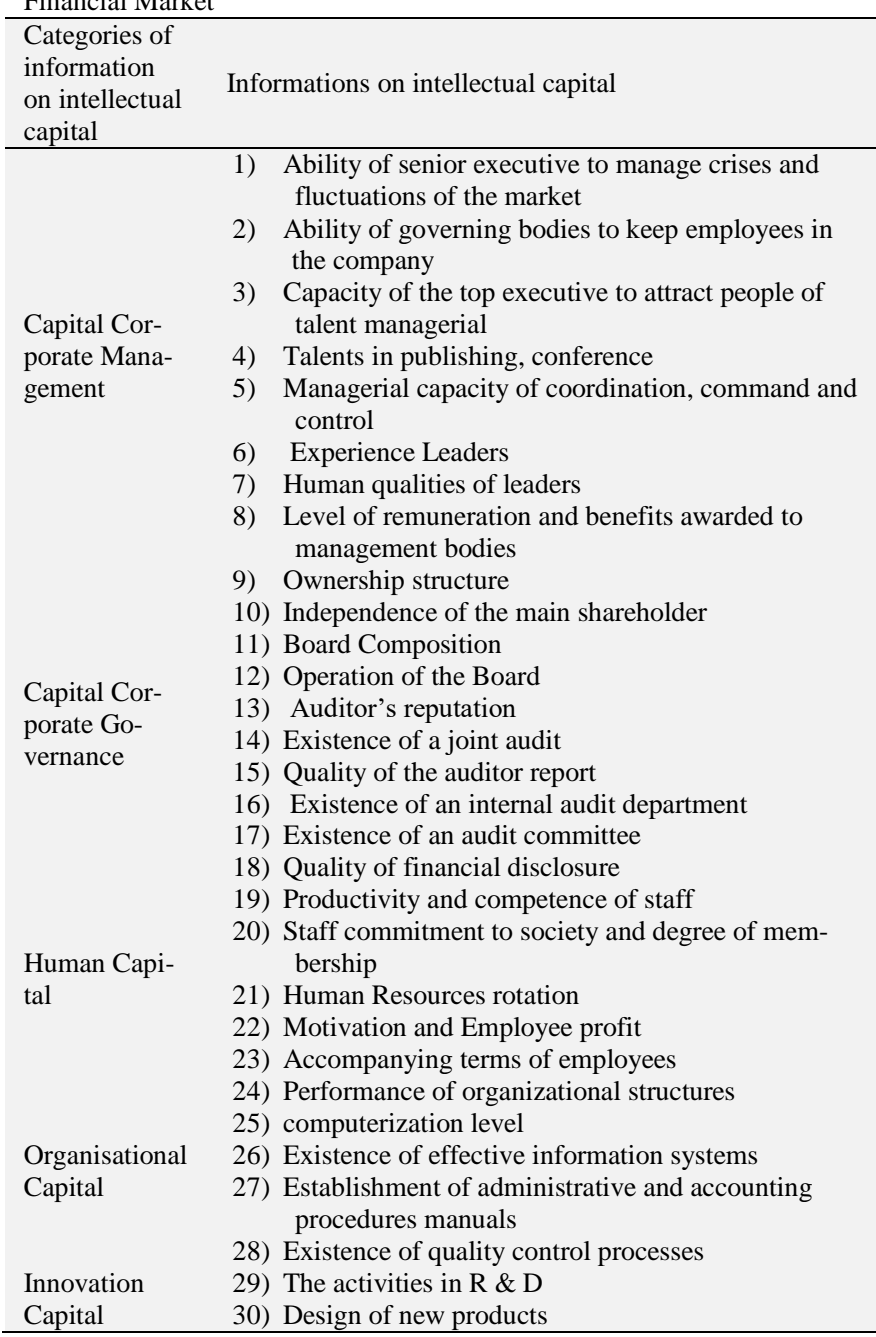

31) Design software adapted to technological innovation

32) Intellectual property

33) Trade licenses

34) Ability to retain customers

35) Taking into account customer expectations to meet Customer

Customer

Capital

36) Customer dependence on Product

37) Company's dependence on customers

38) Company's Market share in the sector

39) Management and control risks related to national and international economic conditions

40) Analysis of competitive advantages and type of competition

External Relations and Risk

Management

41) Competitive positioning in the local market

42) Benefits arising from contracts of partnerships, alliances and synergies

43) Quality of the company's relationship with its environment

44) Consequences of the company's activities on the environment

45) The investments committed to environmental protection

Environmental Ethics Capital

46) Conservation of natural resources and improvement of energy consumption policy

47) Corporate to governmental and environmental standards compliance

Reputation 48) Corporate reputation

Capital

49) Accredited certification to a quality standard ensuring the quality of company products and services

After fixing the list of information from the previous exploration, respondents are asked to decide on the degree of importance of information on the intellectual capoital on the financial market. Thus, they have given a score ranging from 1 to 5 for each list information already defined 1 . Very low importance, 2. Fairly low importance, 3. Moderate importance, 4. Strong enough importance, Very high importance. This operation is done in an iterative manner (three successive iterations).

Thus, during the first stage of the investigation, we took over the list of information on intellectual capital from the exploratory survey already conducted before, and we asked respondents to comment on a Likert scale of 5 points, according to the importance, they attach to the information in question to evaluate the company. We asked respondents to propose amendments to the list already submitted, so as to retain only information deemed relevant in decision making. In fact, we gave them the freedom to add missing information in the list that are considered relevant and remove others if they seem a paltry utility. Similarly, we have given them the freedom to improve the appellations of information, if they are the subject of confusion. At this stage of the Delphi survey, the contribution of financial market experts mainly involves the assignment of a rating that varies according to a scale of 1 to 5 points, with each of the information on intellectual capital according to their level of importance on the market. In the second round, the experts informed of the results of the first round, provided a new response and above are required to justify if it is highly deviant in relation to the group. Thus, at each stage of the Delphi survey, a new questionnaire has been prepared and circulated for the next step. The third and final round of Delphi, gives the definitive answer: a consensus view of opinions.

The results of the first stage show that only 29 of the 49 studied information is subject to a strong consensus. Of the 20 other information, there is no consensus among the experts, which is quite normal at this stage of the method, since the greater convergence between respondents should take place at the end of the following steps. However, we cannot comment on the validity of these results that once the Kendall concordance test performed. Indeed, the calculation of Kendall W allows us to conclude on the general level of consensus among experts. 
Table 6: Kendall Concordance Test - First Stage of Delphi

\begin{tabular}{ll}
\hline Number of Respondents & 22 \\
\hline Kendall W & 0.512 \\
Chi-deux & 633.933 \\
Number of information & 49 \\
Signification asymptotique & $0.000(<1 \%)$ \\
\hline
\end{tabular}

The calculation of the level of agreement gives $\mathrm{K}=0.512$, a high degree of significance. This value of $\mathrm{K}$ corresponds, according to the criteria of Schmidt (1997), an acceptable level of consensus, but below the level considered "high" (0.7). The second stage of the investigation should enable us to improve this level of agreement. During the second stage, we found a greater convergence of the experts' responses. Indeed, the information strong consensus at the first stage was confirmed. Also, the convergence of the information to be little consensus, at the first interview, has improved significantly, demonstrating a clear convergence of views. To confirm this trend, we have calculated, again, the coefficient $\mathrm{W}$ Kendall, according to our methodological approach already described.

Table 7: Kendall Concordance Test - Second Step of Delphi

\begin{tabular}{ll}
\hline Number of Respondents & 22 \\
\hline Kendall W & 0.721 \\
Chi-deux & 893.236 \\
Number of information & 44 \\
Signification asymptotique & $0.000(<1 \%)$ \\
\hline
\end{tabular}

Kendall test indicates, at the end of this second step, a W> 0.7 . Thus, we can consider that the level of consensus in this phase is high, a high degree of significance. We can therefore conclude that a significant convergence of responses between the two stages of the Delphi method. The last step is only a confirmatory phase which was obtained in the previous step, since the level of agreement has been improved considerably.

Table 8: Kendall Concordance Test - Last Step of Delphi

\begin{tabular}{ll}
\hline Number of Respondents & 22 \\
\hline W Kendall (a) & 0.732 \\
Chi-deux & 905.946 \\
Number of information & 42 \\
Signification asymptotique & $0.000(<1 \%)$ \\
\hline
\end{tabular}

Information on intellectual capital adopted by consensus at the end of the Delphi method carried out in 3 steps are summarized in Table 9.

Table 9: The Information Needs in Intellectual Capital Retained by Consensus

\begin{tabular}{lll}
\hline $\begin{array}{l}\text { Categories of infor- } \\
\text { mation on intellectual } \\
\text { capital }\end{array}$ & Informations on intellectual capital \\
\hline & 1) & Manager Competence \\
& 2) & Capacity of the manager to keep em- \\
ployees in the company
\end{tabular}

20) Motivation and Employee profit

21) Accompanying terms of employees

22) Performance of organizational structures

23) Existence of effective information systems

Organisational Capital

24) Establishment of administrative and accounting procedures manuals

25) Existence of quality control processes

26) The activities in R \& D

27) Design of new products

Innovation Capital

28) Design software adapted to technological innovation

29) Intellectual property

30) Trade licenses

31) Ability to retain customers

Customer Capital

32) Customer dependence on Product

33) Company's dependence on customers

34) Company's Market share in the sector

35) Management and control risks related to national and international economic conditions

External Relations and Risk Management

36) Competitive positioning in the local market

37) Benefits arising from contracts of partnerships, alliances and synergies

38) Quality of the company's relationship with its environment

39) The investments committed to environmental protection and to conservation of natural resources

Environmental Ethic Capital

40) Corporate to governmental and environmental standards compliance

41) Corporate reputation

Reputation Capital

42) Accredited certification to a quality standard ensuring the quality of company products and services

Table 10 defines the categories of information on the intellectual capital most valued by the financial market participants.

Table 10: The Order of Relevance Attributed to the Various Categories of Information on Intellectual Capital

\begin{tabular}{lll}
\hline Categories of information on intellectual capital & Mean & Median \\
\hline Innovation Capital & 4.952 & 5 \\
External Relations and Risk Management & 4.941 & 5 \\
Capital Corporate Management & 4.904 & 5 \\
Capital Corporate Governance & 4.904 & 5 \\
Reputation Capital & 4.857 & 5 \\
Human Resources & 4.523 & 5 \\
Customer Capital & 4.381 & 4 \\
Organisational Capital & 4.190 & 4 \\
Environmental Ethics Capital & 3.952 & 4 \\
\hline
\end{tabular}

Table 10 shows that innovative capacity is the most important category of information in the financial market. Experts interviewed ascribe an average of 4.952 on a maximum value of 5 . They consider that innovation is a key lever for long-term growth of the economy and an essential strategic asset since it founded the welfare of future generations, and this category of information is most valued in the financial market. Similarly, the information category related to the External Relations and Risk Management is highly valued by the financial markets since the potential of the company's interactions with its environment is an asset. Reading this table also shows that the information category for the management of the company and its governance are particularly important because their experts interviewed attribute an average of 4.9. However, the category of information relating to environmental ethics seems to be the least requested by the financial market. The majority of respondents thinks that these concepts are not sufficiently rooted in the Tunisian context and added that the actions of environmental ethics are a luxury we will not afford to currently in an emerging country. 


\section{Conclusion and implication}

At the end of this study, we defined by consensus the intellectual capital as perceived by the financial market. Our survey of financial analysts and portfolio managers, allowed us to define intellectual capital as consisting of nine elements: "Capital Corporate Management », «Capital Corporate Governance », « Human Resources », « Organisational Capital », « Customer Capital », « External Relations and Risk Management », «Environmental Ethics Capital » and « Reputation Capital ».

If this definition is not different from the academic literature, however our study has clearly highlighted the importance of « Capital Corporate Management », " Capital Corporate Governance », «External Relations and Risk Management », and «Innovation Capital » in the definition of intellectual capital. In this sense, our study can supplement existing work and allows carrying a definition of the concept intellectual from a financial perspective.

According to the respondents (financial analysts and portfolio managers), these components must guarantee the development of the intellectual capital of the company. Interest in these components is confirmed by our Delphi survey. These elements collect the highest ratings compared to other components of capital identified intellectual. The consensus results of the Delphi survey for the definition of intellectual capital can be considered a model for companies who wish to report the quality of their intellectual capital in the financial market.

This result implies that the companies should seek to disclose these items. This research raises the awareness of the Tunisian managers to pay attention to their voluntary disclosure in the annual reports to meet the growing information needs of their external users regarding the intellectual capital.

Like any research effort, our work suffers from a number of deficiencies among which the small size of the sample (22 respondents). Like the most qualitative research, in addition to the subjective nature of the data collected, this study was limited to the interrogation of the only financial analysts and portfolio managers. Today's concept of intellectual capital remains a notion that raises the interest of all stakeholders. In future research, it is proposed to extend the study to other financial players, bankers, accountants, institutional investors.

This research provides some lines of thought that should be explored further. Our research can only help the launch of a debate on intellectual capital disclosure and the improvement of the quality of the external reporting. Other qualitative studies could be carried out about the confrontation between supply and demand for Voluntary intellectual capital information in the Annual Reports.

\section{Acknowledgement}

The author would like to thank her Ph.D supervisor Professor Robert Paturel for his contribution and his valuable comments.

\section{References}

[1] Ahmed A and Hussainey K (2010) Managers' and auditors' perceptions of intellectual capital reporting. Managerial Auditing Journal, $\begin{array}{llllll}\text { Vol. } & 25 & \text { Iss: } & 9, & \text { pp. } 844 & -\end{array}$ http://dx.doi.org/10.1108/02686901011080035.

[2] Barth M E, Clement M B, Foster G, and Kasznik R (2000) Brand values and capital market valuation. Review of Accounting Studies, Vol. 3, pp.41-68. http://dx.doi.org/10.1023/A:1009620132177.

[3] Beattie V and Pratt K (2002b) Disclosure items in a comprehensive model of business reporting: an empirical evaluation. Working paper, University of Stirling.

[4] Béjar Y (2006) Perception du capital immatériel par le marché financier français. Journal International des Sciences de l'Information et de la Communication, $\mathrm{n}^{\circ} 33, \mathrm{p} 10-15$.

[5] Béjar Y (2006) La valeur informationnelle du capital immatériel: application aux entreprises technologiques nouvellement introduites en bourse (1997-2004). Working paper; université paris Dauphine, Novembre 2006, p 80-83.

[6] Belal A and Roberts R (2010) Stakeholders' Perceptions of Corporate Social Reporting in Bangladesh. Journal of Business Ethics, 97(2): 311-324. http://dx.doi.org/10.1007/s10551-010-0511-4.

[7] Breton $G$ and Taffler R (2001) Accounting Information and Analyst Stock Recommendation Decisions: A Content Analysis Approach. Accounting and Business Research, Vol. 31, $\mathrm{N}^{\circ}$ 2, spring, pp. 91 101. http://dx.doi.org/10.1080/00014788.2001.9729604.

[8] Bounfour A (2000) La valeur dynamique du capital immatériel. Revue Française de gestion, $\mathrm{n}^{\circ} 17$, pp 111-123.

[9] Bukh N (2003) the relevance of intellectual capital disclosure: a paradox? Accounting, Auditing \& Accountability Journal, Vol. 16, Issue 1, pp. 49-56. http://dx.doi.org/10.1108/09513570310464273.

[10] Cazavan A (2004) Le ratio market-to-book et la reconnaissance des immatériels - Une étude du marché français. Comptabilité Contrôle Audit, Tome 10, Vol. 2, décembre.

[11] .Chahine S and Mathieu J (2003) Valorisation stratégique par contextes de valeur: le cas des introductions sur le Nouveau marché. Revue Finance Contrôle Stratégie, Vol. 6, issue 2, p 91-114.

[12] Curado C (2008) Perceptions of knowledge management and intellectual capital in the banking industry. Journal of Knowledge Management, Vol. 12 Issue: 3, pp.141 - 155 http://dx.doi.org/10.1108/13673270810875921.

[13] Eccles R G, Hertz R H, Keegan E M and Phillips D M (2001) The Value Reporting Revolution: Moving Beyond the Earnings Game. New York, United States of America: John Wiley and Sons.

[14] Edvinsson L and Malone M (1997) Intellectual Capital: Realizing your company true value by finding its hidden Brainpower. Harper Business, 1997, New York.

[15] Feranadez. E, Montes J.and Vazquez C (2000) Typology and Strategic analysis of intangible resources: A resource-based approach. Innovation, Vol. 20, pp. 81-92.

[16] Ferreira A and Martinez L (2011) Intellectual capital: Perception of Productivity and Investment. RAC, Curitiba, v. 15, n. 2, art. 5, pp. 249-260, Mar. /Abr. 2011. http://dx.doi.org/10.1590/s141565552011000200006.

[17] Frotiee P and Andrieu M (1998) Valeur actionnariale et immatérielle. Analyse financière, $\mathrm{n}^{\circ} 116$.

[18] García-Meca E and Martínez I (2007) The use of intellectual capital information in investment decisions: An empirical study using analyst reports. The International Journal of Accounting, Vol 42, pp. 57-81. http://dx.doi.org/10.1016/i.intacc.2006.12.003.

[19] Healy P and Palepu K (2001) A review of the empirical disclosure literature. Journal of Accounting \& Economics, Vol. 31, Issues 1-3.

[20] Lev B (2001) Intangibles: management, measuring and reporting. Brookings Institution Press, Washington,DC .

[21] Lev B and Radhakrishnan S (2003) The Measurement of firmspecific organisation capital. Working Paper, $\mathrm{n}^{\circ} .9581$.

[22] Mavrinac S and Siesfeld A (1997) Measures that matter, An exploratory investigation of investors information needs and value properties. In Enterprise Value in the Knowledge Economy, OECD and Ernst \& Young Center for Business innovation, Cambridge, MA.

[23] Miller W (1999) Building the Ultimate Resource. Management Review, Jan. 1999, 42-45.

[24] Schmidt R (1997) Managing Delphi surveys using nonparametric statistical techniques. Decision Sciences, Vol. 28, n³, pp. 763-774. http://dx.doi.org/10.1111/j.1540-5915.1997.tb01330.x. 